\title{
sciendo
}

RESEARCH PAPERS FACULTY OF MATERIALS

SCIENCE AND TECHNOLOGY IN TRNAVA

SLOVAK UNIVERSITY OF TECHNOLOGY

IN BRATISLAVA

2019, Volume 27, Number 44

DOI 10.2478/rput-2019-0017

\section{RISKS RESULTING FROM REVERSE OF MODIFICATION OF EXPANSION WEAPONS}

\author{
Pavol ČEKAN ${ }^{1}$, Eugen BELICA ${ }^{2}$, Daynier Rolando Delgado SOBRINO² \\ ${ }^{1}$ SLOVAK UNIVERSITY OF TECHNOLOGY IN BRATISLAVA, \\ FACULTY OF MATERIALS SCIENCE AND TECHNOLOGY IN TRNAVA, \\ INSTITUTE OF INTEGRATED SAFETY, \\ Ulica JÁna BotTu 2781/25, 91724 TRNAVA, SLOVAK REPUBliC \\ ${ }^{2}$ SLOVAK UNIVERSITY OF TECHNOLOGY IN BRATISLAVA, \\ FACULTY OF MATERIALS SCIENCE AND TECHNOLOGY IN TRNAVA, \\ INSTITUTE OF PRODUCTION TECHNOLOGIES, \\ Ulica JÁNA BotTu 2781/25, 91724 TRNAVA, SLOVAK REPUBLIC \\ e-mail:pavol.cekan@stuba.sk, eugen.belica@stuba.sk,daynier.sobrino@stuba.sk \\ Received: 20.05.2019, Accepted: 17.06.2019, Published: 25.07.2019
}

\begin{abstract}
In general, the probability of an undesirable event occurring and its consequence is the gist of the risk characteristics. Thus, risk is part of all the activities that a person performs. The use of weapons and possession of weapons is a great risk. It makes difference who owns them, where they are used and under what circumstances. At present, the great risk is also associated with the possession and use of expansion weapons, also called acoustic weapons. This issue is still very sensitive; the aim of this article is to highlight the risks of reverse modification of such weapons. Publication of this contribution does not support or otherwise supports the use and sale of any type of weapons.
\end{abstract}

\section{Key words}

Risk, legislation, expansion weapon, reverse modification

\section{INTRODUCTION}

The whole period of development of firearms up to the present has contributed to a complex definition of the concept of a firearm. A firearm can be defined as a machine or equipment designed to kill people and animals, or to destroy objects at a distance thrown by the solid (projectile) or subject structurally derived, whose missile sets an immediate release of accumulated energy [1].

The definition of weapon varies, but the essence is preserved. The first definition of firearm shows some differences and additions to that defined by the Act $190 / 2003$. The gun, according to the aforementioned law, is a portable device that fires designed to fire a missile, and whose 
function is to immediately release energy at a shot. Furthermore, parts of the weapon, replica weapons and imitation weapons are also considered a weapon [2].

As the main objective of the paper is to determine the risks in the modification of expansion weapons, it is also appropriate to know the general requirements of legislation. For a better understanding of the definition of an expansion weapon, it is important to start with general categorization under the law. Following are the laws used in the Slovak Republic, but their content is in line with the requirements of the European Union.

Arms legislation currently in force and ammunition is treated in the Slovak Republic by the Act 190/200 “on Firearms and Ammunition". This Act establishes the types and categories of firearms and ammunition, the conditions for acquiring ownership, possession, carrying and using the weapons and ammunition, the rights and obligations of holders of weapons and ammunition, conditions for the export, import and transport of weapons and ammunition, conditions for the establishment and operation of firearms, conditions for displaying weapons and ammunition; it regulates the operation of information systems in the field of weapons and ammunition, supervision function over compliance with this Act and provides for sanctions for breach of obligations under this Act. According to this Act, weapons and ammunition are divided into appropriate categories that specify their design solutions. The categories of weapons and ammunition under the Act are as follows:

- Category A weapon; category A weapon is a prohibited weapon, prohibited ammunition, and prohibited weapon accessories.

- Category B weapon; this category includes weapons which are subject to authorization and registration.

- Category $\mathbf{C}$ weapon; this category includes weapons that are subject to reporting and recording obligations.

- Category $\mathbf{D}$ weapon; this category includes weapons that are subject to reporting and recording obligations.

Ammunition for Category A to D weapons that are not prohibited.

The following table further categorises firearms in prescribed categories [2].

Table 1 Detailed categorization of weapons according by to teh Act 190/2003 in the Slovak Republic [2]

Categorization of weapons according to Act 190/2003 Category A weapon Category B weapon

a) military weapon,

b) automatic weapon,

c) a weapon with its original character and appearance to change so that it can be caused by its use of harder consequence as before, or a weapon, which has the appearance of another subject,

d) a firearm made of non-metallic material and not identifiable by means of detection devices and X-ray machines,

e) weapon with a firmly mounted shot silencer,

f) weapon with a fixed laser sight, sights designed on procedure of noktovízor, infrared, electronic image magnification and image flipping devices,

a) a short repeating firearm, or a short selfcharging firearm,

b) short single-shot firearm for ammunition with central inflammation,

c) single shot firearm for ammunition with marginal inflammation whose total length is less than $280 \mathrm{~mm}$,

d) a long semi-automatic weapon whose magazine and chamber can collect more than three cartrige together,

e) a long semi-automatic firearm whose magazine and chamber cannot collect more than three cartridges together and whose delivery device is removable, or where it is not guaranteed that it cannot be altered by commonly available weapon tools whose magazine or 


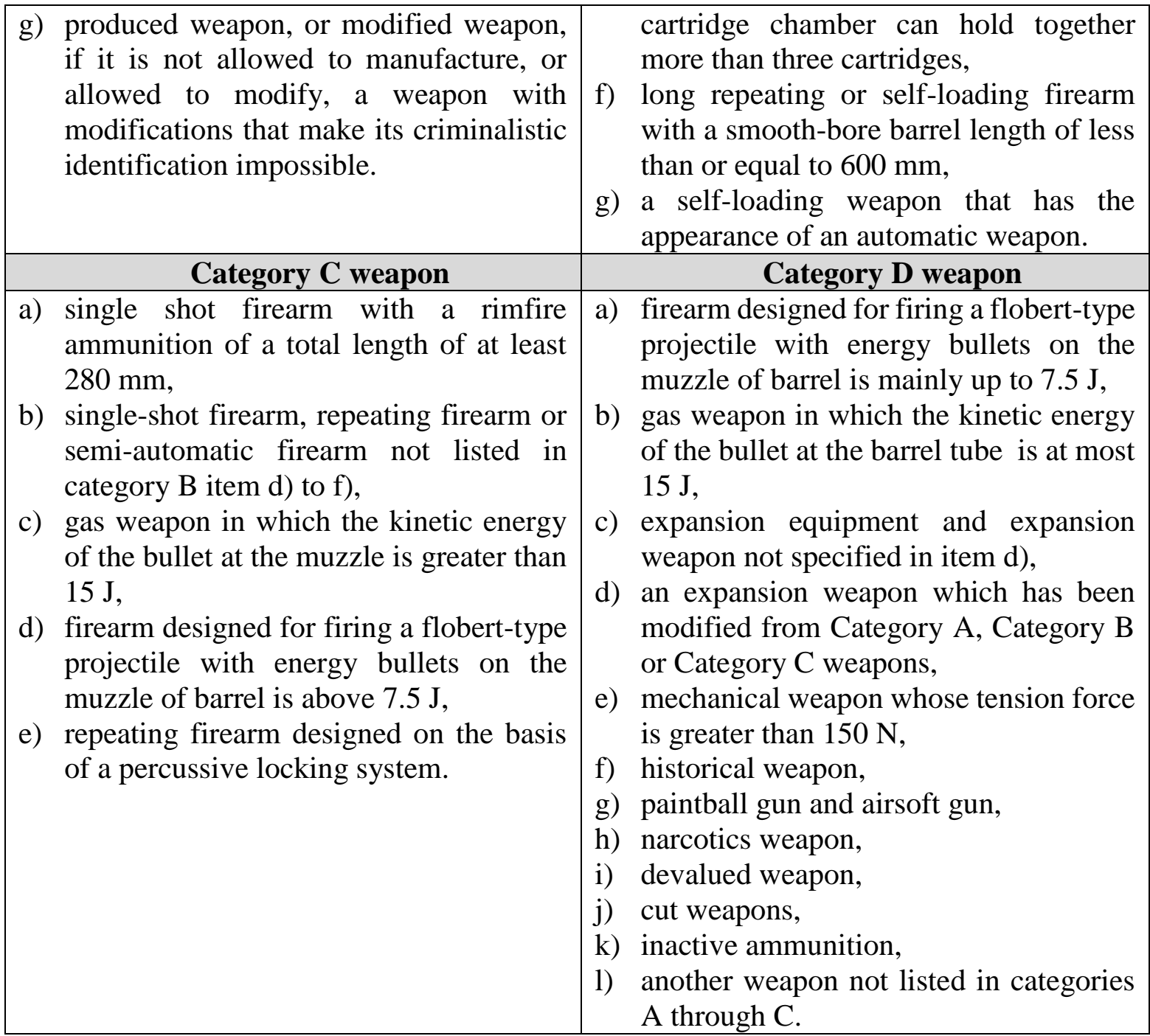

According to the categorization and other requirements of the law, an expansion weapon is defined as a firearm designed solely for the use of ammunition intended for expansion weapons, excluding the use of spherical charge, or ammunition with a multiple bullet excluding a bullet with granules [2].

Expansion weapons are classified in category D under this law. As far as the acquisition of such weapons is concerned, those requirements are set out in Section14, which states that Category $\mathrm{D}$ weapon, or ammunition for this weapon may be owned by a legal person, or a personal entity older than 18 years, who is fully eligible for legal acts [2].

Significant changes that occurred in Act No. 190/2003 Coll. also took place at the instigation of the European Union, which was based on the first terrorist attacks in France, where expansion weapons with a reversible modification were used for sharp weapons.

Changes to this Act have been implemented by Act No. 120/2015 Coll. of 14th May 2015 which ammends Act No. 190/2003 Coll. on firearms and ammunition.

According to the implemented changes to category D, (Table 1), the following items were added:

a) expansion equipment and expansion weapon not specified in item d),

b) expansion weapon which has been modified from Category A, Category B or Category C weapons,

c) paintball gun and airsoft gun,

d) narcotics weapon, 
e) devalued weapon,

f) cut weapons,

g) inactive ammunition $[2,4]$.

The holder of a Category D weapon is required to carry an identity document when handling this weapon and, in the case of a weapon holder of category D listed in Table 1, item (d), also a weapon license. The holder of a Category D weapon shall not carry the weapon visibly $[2,4]$.

Another change is in the acquisition of arms and ammunition. He who acquires the possession of a weapon of category $\mathrm{D}$ referred in Table 1 item $\mathrm{d}$ ) is obliged to notify the police department of the acquisition of the possession of the weapon within seven days of the date on which the weapon is acquired; at the same time, he is obliged to submit a registration weapon within this period [2,4].

Furthermore, it is forbidden to enter into a distance contract for the purchase and sale of the category A, category $\mathrm{B}$ and category $\mathrm{C}$ weapons or ammunition for such weapons, an expansion weapon, weapons that have been destroyed by category A weapons, categories B and category $\mathrm{C}$ and weapons of category $\mathrm{D}$ referred in Table 1 item 1), unless otherwise specified $[2,4]$.

\section{ADJUSTMENT METHODOLOGY AS THE BASIS FOR IDENTIFYING POSSIBLE RISKS}

Amendment to the Law on ammunition weapons has also brought changes in the methodological procedure for the modification of weapons categories $\mathrm{A}, \mathrm{B}, \mathrm{C}$ to an expansion gun. This section provides a description of the technical procedure for modification the expansion weapon. This procedure was implemented by the regulation of the Office for Standardization, Metrology and Testing of the Slovak Republic No. 169/2015 Coll [3].

For the modification of the above mentioned categories of weapons (categories A, B, C) up to the category $\mathrm{D}$ expansion weapon, the following methodological procedure shall be followed:

a) main parts of the weapon of category $\mathrm{D}$ shall be modified so that the use of the mechanical properties of the material does not allow the reverse modification of the Category D weapon to a weapon capable of being loaded and fired with ammunition intended for a Category A, B, C weapon,

b) in barrel at Category $\mathrm{D}$ weapon, the barriers are placed, the removal of which will destroy the barrel (Fig. 1, 2), [3],

c) the size of the cartridge chamber of the $\mathrm{D}$ category are that ammunition intended for arms of categories A, B, C cannot be fired,

d) for a Category $\mathrm{D}$ weapon with a pushed-in chamber when attempting to remove it in barrel, it will damage its non-detachable joint with the seal housing,

e) muzzle cartridge chamber of revolver cylinder Category D weapons will narrow and push against the barrel,

f) for a Category $\mathrm{D}$ weapon whose construction is designed so that in normal handling and cleaning of the weapon it is possible to disassemble the main parts, these main parts must not allow them to fire ammunition intended for weapon category A, B, C [3].

It is clear from the steps a) and b) of the methodological procedure and from Figure 1 that the modification is directed to the gun barrel. Figure 1 a) shows the use of a steel stopper, which is welded into the barrel or screwed and then welded. A steel pin is also used instead of a steel stopper. Such modification is carried out mainly on the muzzle of the weapon. Figure $1 \mathrm{~b}$ ) shows a hard modification at the cartridge chamber. There is a cut out of the barrel weapon to 
the bore hole. Then, the throughput is a barrel modification by inserting and welding the metal plate.

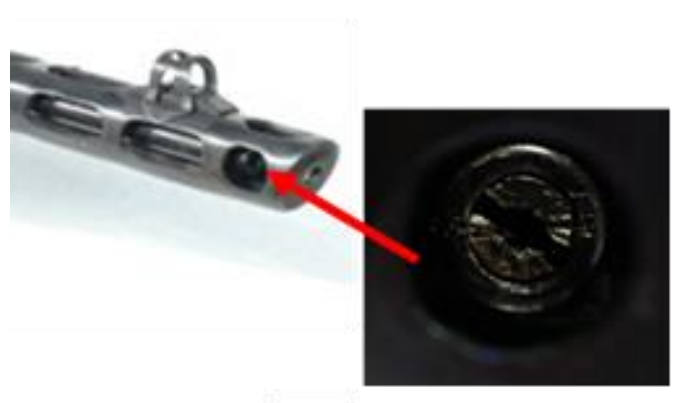

a)

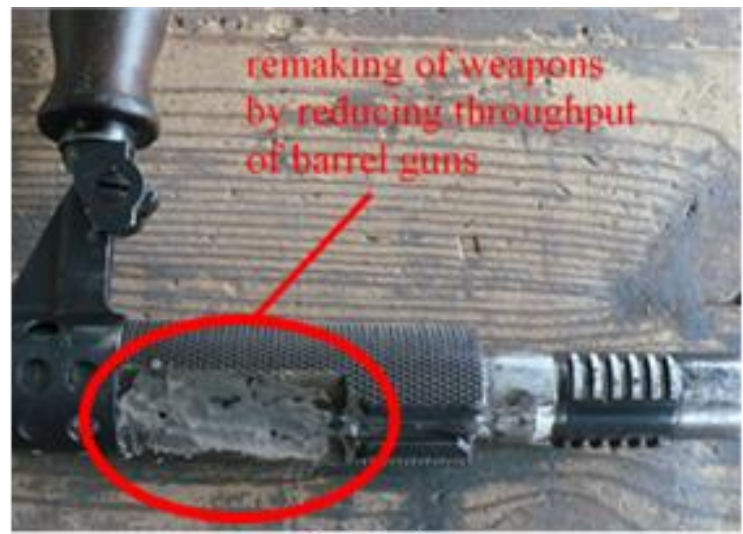

b)

Fig. 1 Modification of barrel of the expansion gun of category $D$ a) insertion of a steel stopper with a small opening, $b$ ) milling of the barrel and insertion of a barrier and welding

The treatment methods described are done at both ends of the gun. Such a modification is made for both short and long guns. For better idea, Figure 2 is shown in more detail.

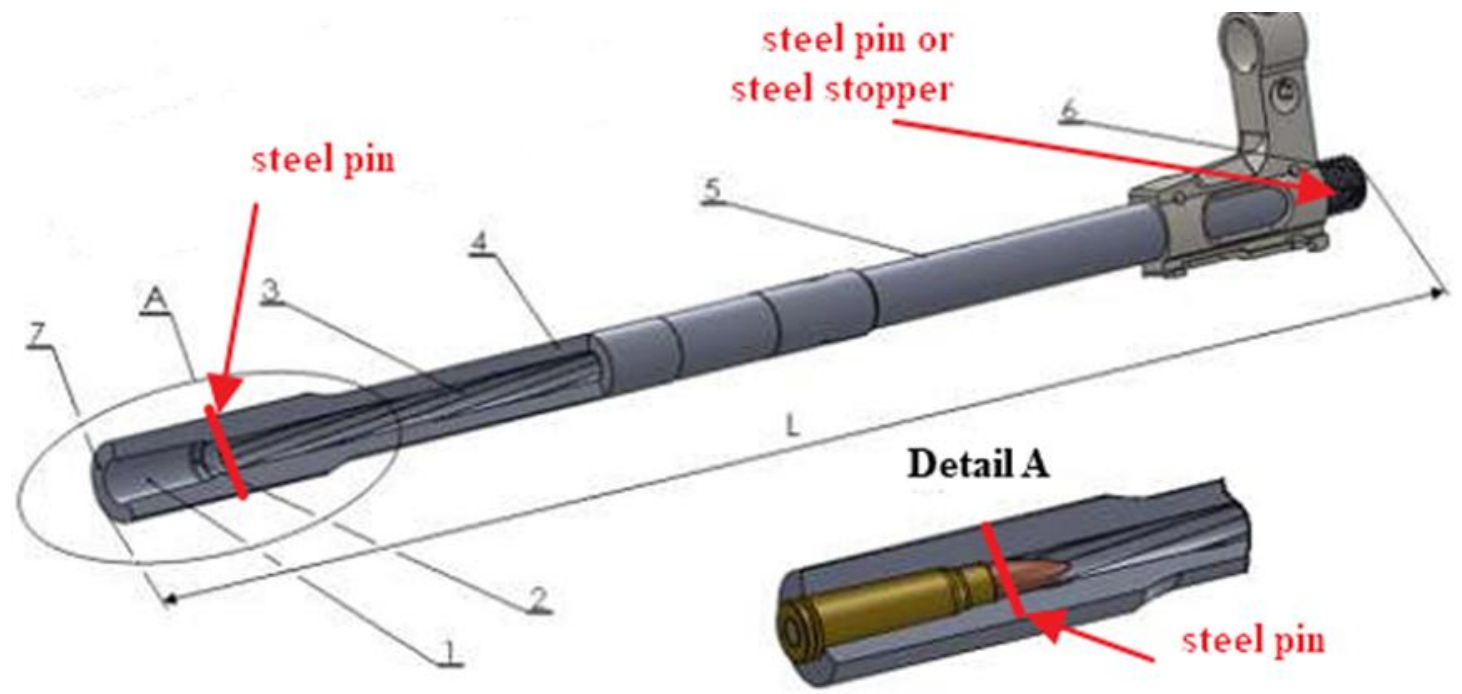

Fig. 2 A detailed representation of the location of the steel pin or steel stopper after barrel modification a D-category expansion weapon. Description of particular parts of barrel:

1- cartridge chamber, 2- connecting cone, 3- groove bore barrel,, 4-wall barrel, 5- outer surface barrel, 6-muzzle barrel, 7-rear forehead, L- barrel length, A- detail of the cartridge chamber with inserted cartridge [5]

Figure 2 shows the exact location of the steel pins or the steel stopper. The pins are inserted into the drilled holes and then welded. The pins are placed at both ends of the barrel. The first is inserted into the opening in the cartridge chamber behind the connecting cone. The cartridge chamber is thus shortened by the length of the projectile. The second pin is placed under the Front Sight Base or in front of it. It is clear from detail A that if a steel pin is inserted in front of the connecting cone, it will not be possible to insert a sharp charge into the modification of expansion gun of category D. 
The category A, B, C weapons that are modified under this regulation may use ammunition (bag cartridge) as shown in (Fig. 3 a), b)). For comparison, Fig. 3 c) displays the sharp ammunition.

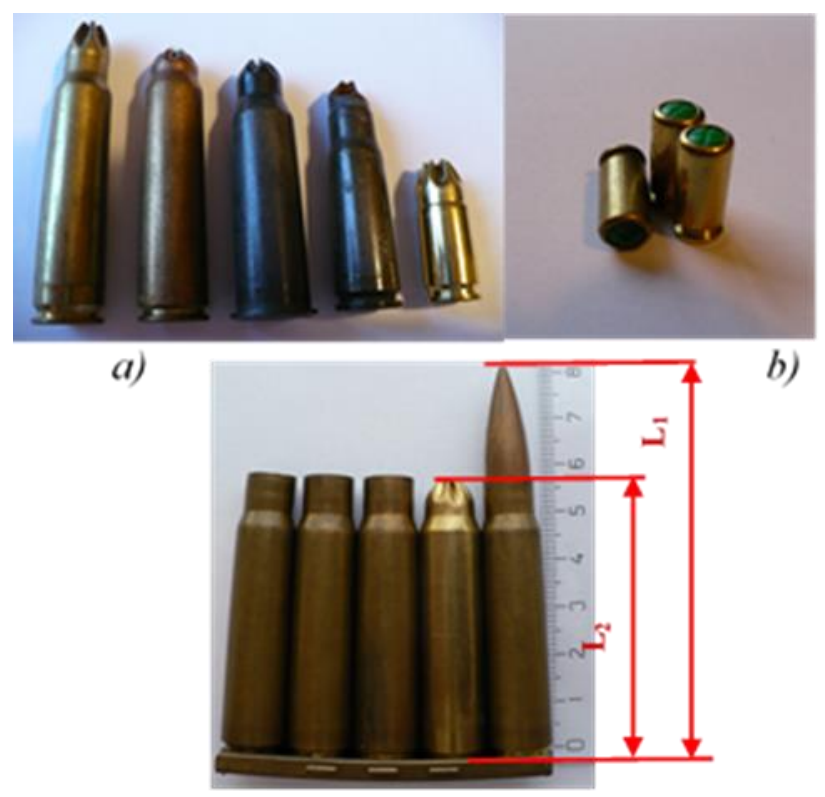

c)

Fig. 3 a), b) blind cartridge usable only in expansion weapons, c) comparison of sharp cartridge and blank cartridge, where $L_{1}$ is the actual length and $L_{2}$ the length without the projectile

Figure 3 shows a clear distinction between blind cartridge and sharp cartridge. Figure 3 shows a comparison with a specific cartridge of a $7.92 \times 57 \mathrm{~mm}$ caliber, which is used in long arms. Dimension $L_{1}$ is the entire length of the sharp cartridge $81 \mathrm{~mm}$. The $\mathrm{L}_{2}$ dimension is a 57 $m m$ blind cartridge without a projectile. Differences in the dimensions of the cartridges are also used in cartridges used for short weapons.

After modifing, the expansion weapons were sometimes referred to only as ammunition caliber number by word CVICNY or BLANK, and the last two digits of the year in which the modifing was made. From August 1st, 2015 according to the Act No. 169/2015 Coll. the marking of the expansion weapon is to be made permanent and in a visible manner by a control expansion label (Figure 4 a), b), c)). This marking indicates the barrel and at least one other part of the weapon [3]. 


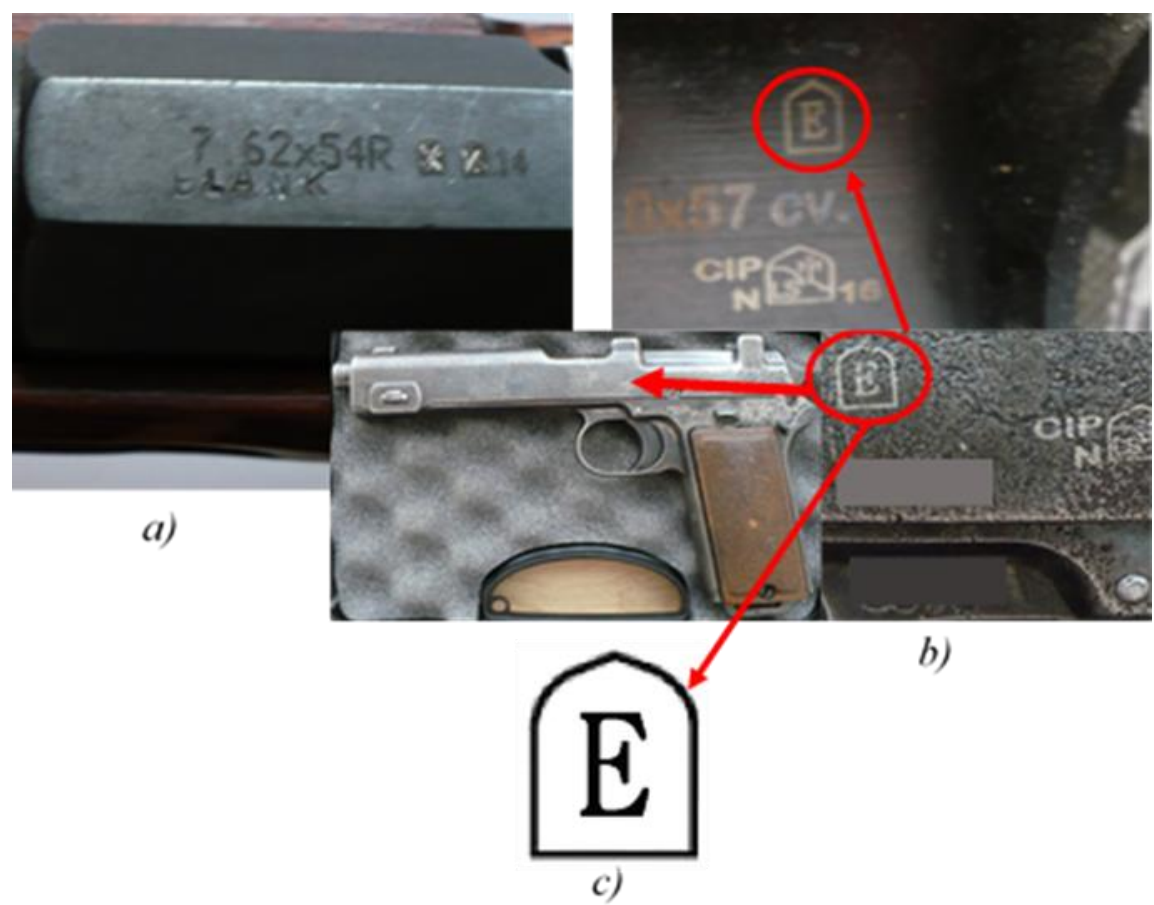

Fig. 4 Types of the expansion weapons marking:

a) designation of the expansion weapon before to the introduction of the control mark-old method of designation, $b$ ) designation of the expansion weapon of the control mark - a new method of designation, c) a new control expansion mark used since 2015 [3]

In such a modification of the weapon categories A, B, C to category D expansion weapon as shown in Figures 1 and 2, it is no longer possible to reverse modification to a sharp weapon without destroying the barrel or the chamber. For the possibility of a sharp shooting, it is necessary to replace the barrel.

\section{RESULTS AND DISCUSSION ON RESULTS}

Despite the modification of weapon category A, B, C, the expansion weapon also poses a number of risks related to its design, modification, use and further handling (maintenance and cleaning). This part of the contribution will mainly focus on the risks arising from the reverse modification of the Category D expansion weapon to Category A, B, and C weapons.

The actual modification of the expansion weapon according to the former Act 169/2015 is to prevent its re-modification. However, some expansion weapons may not always undergo a modification that significantly affects the integrity of some components such as the barrel (see Figure 1b)). Some modifications are made so that the steel pin is inserted and welded at the end, mostly under the Front Sight Base. The pin welded in the barrel performs a very important function as a barrier. This means that the purpose of this barrier is to prevent the use of a sharp cartridge. In such a case, the sharp cartridge would stick out of the cartridge chamber and it would not be possible to close the cartridge chamber by the Bolt. The cartridge would stick from the cartridge chamber to the full length of the projectile $L_{1}-L_{2}$ according to Figure $3 \mathrm{c}$ ). If someone tried it by force, it would cause damage to the cartridge or the weapon's Bolt. The risk of cartridge explosion is eliminated because the Bolt will not be locked and the Firing Pin will not be tight. When the Trigger is depressed, the Firing Pin does not release and ignites a match cartridge [3].

In the reverse modification of the expansion weapon, the steel pin or the steel stopper must be removed from the Barrel weapon. The pins must first be drilled. The holes that remain after 
the pins extend through the entire cross-section of the Barrel. These holes must be re-welded. This has to be done by a skilled weapons master. This is not a simple operation because each barrel is made of a different material depending on the purpose of ustilisation of the weapon it was designed for before it was modified to an expansion weapon of category D.

A variety of materials are used in the construction of weapons. The choice of material type also depends on the type and intensity of the stress of a particular part of the weapon. Since the modification is aimed at the barrel of the weapon, the barrel belongs to the category of the most stressed parts. So, in particular, only noble metal materials are used in the barrel production. In general, such materials must meet the following requirements [5]:

- high strength,

- enough toughness,

- hardness required,

- resistance to thermal stress (heat resistance, low coefficient of thermal expansion),

- chemical stability,

- abrasion and erosion resistance from dust gases,

- good machinability.

This material must retain its properties even within a large thermal range. The temperature of the burning gases in the barrel bore typically ranges from 2000 to $2800 \mathrm{~K}$. For this reason, heat resistance is one of the important properties. At the same time, the weapon can be used in difficult conditions at the temperatures of cca. $-40^{\circ} \mathrm{C}$. In such a situation, the barrel of the

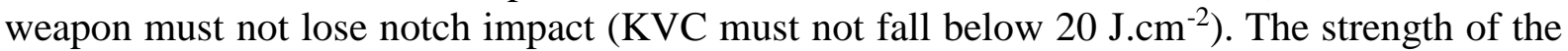
material is also influenced by the wall thickness of the barrel, which must withstand a pressure of $500 \mathrm{MPa}$. In terms of durability, important is resistance to abrasion and erosion. Generally, weapons are designed for long-term operation, so these specifications must not be forgotten [5].

Currently, achieving high levels of strength steel is not a problem. The limiting factor is good machinability of the material. The best of these properties are met by the alloy steel class 11 to 16 . Table 2 shows the basic ingredients used in manufacturing and their contribution to the properties of alloys. Compared to conventional steels, high demands are placed on homogeneity, purity and chemical composition. Chemical composition is the know-how of any company that produces weapons. Unevenness in the structure of the material can cause unwanted deformations in heavy duty operations [5].

\begin{tabular}{|l|l|l|l|l|}
\hline \multicolumn{5}{|c|}{ Table 2 Essential ingredients for steels for barrel production [5] } \\
\hline $\begin{array}{c}\text { Native } \\
\text { element }\end{array}$ & $\begin{array}{c}\text { Element } \\
\text { mark }\end{array}$ & $\begin{array}{c}\text { General } \\
\text { content }\end{array}$ & \multicolumn{2}{|c|}{ Benefit for } \\
\hline Chromium & $\mathrm{Cr}$ & from $1.5 \%$ & $\begin{array}{l}\text { Increasing the heat resistance and abrasion } \\
\text { resistance }\end{array}$ \\
\hline Nickel & $\mathrm{Ni}$ & from $4 \%$ & $\begin{array}{l}\text { reducing the decrease in toughness with a decrease } \\
\text { in temperature }\end{array}$ \\
\hline Molybdenum & $\mathrm{Mo}$ & from $0.5 \%$ & relieving sensitivity to temper brittleness \\
\hline Vanadium & $\mathrm{V}$ & from $0.3 \%$ & fine alloy structure \\
\hline
\end{tabular}

In addition, tungsten and titanium, silicon, or copper can also be used. The chemical composition and the content of the ingredients is a very important factor with respect to the mechanical properties. The breaking strength $R m$ ranges from 750 to $1100 \mathrm{MPa}$, and up to 1700 MPa for high performance cannons [5, 6].

From a more detailed specification of the materials used in the barrel production, it is clear that carrying out reverse modification can be challenging. Removing the pins from the barrel and welding the holes out of the pins may not provide the desired quality. By welding the holes, the desired homogeneity of the barrel may no longer be achieved. Removing the steel pins (the 
prescribed barriers) will make the barrel fully passable, then it is again a weapon of categories A, B, C by law. Such a reverse modification of barrel poses the greatest risk to the function of the weapon, but also the risk to the user's health.

We have identified the greatest risk associated with the damage to the weapon, but also the damage to the health of the user. Due to the reverse modification sharp shooting is possible without problems as long as the welded spots do not get damaged by pressure, friction of the bullet, rapid temperature rise, of course, it also depends on whether it is a automatic weapon, self-loading weapon or repeating weapon.

This raises an important fundamental question whether it is possible to live shoot without any further damage to the weapon, or worse, there is a risk of injury user's of this weapon. The answer to this question is based on the following facts.

The fundamental fact that shooting sharply often uses larger grams of dust charge (gunpowder) cartridge than the blind cartridges used in expansion weapons. It should be noted that the probability of damage to a weapon or user is much greater.

Another fact is that the weld at the repaired points where the steel pin may have hidden defects, such as: pores that result from increased electrode moisture, presence of impurities, high welding speed or there may be cracks in the welded joint due to the fact that the base material has a higher carbon content, manganese or other ingredients, too rapid cooling in the heat affected area and high humidity. As a result, in the case of repeated firing, the weld or weld spot in the barrel is damaged and then the projectile is blocked and the barrel bursts. This may already have serious health consequences for the user. These facts affect the inner ballistics of the weapon, which examines the phenomena at the shot which takes place in the barrel: the course of gas pressure, its temperature, the emergence and development of the speed of the bullet in the barrel. The inner ballistics is determined by the type of gunpowder used, its shape and quantity, the size of the initial combustion space and the length of the barrel [7].

Very important is what happens with the weapon barrel at the shot. When shooting during projectile transition, vibrations occur in the barrel. The frequency and amplitude depends on the thickness of the barrel wall. The greater the thickness of the wall barrel, the smaller the vibration. In vibration, all of its points oscillate around its normal position. Figure 5 shows a schematic representation of a weapon barrel oscillation method [7].

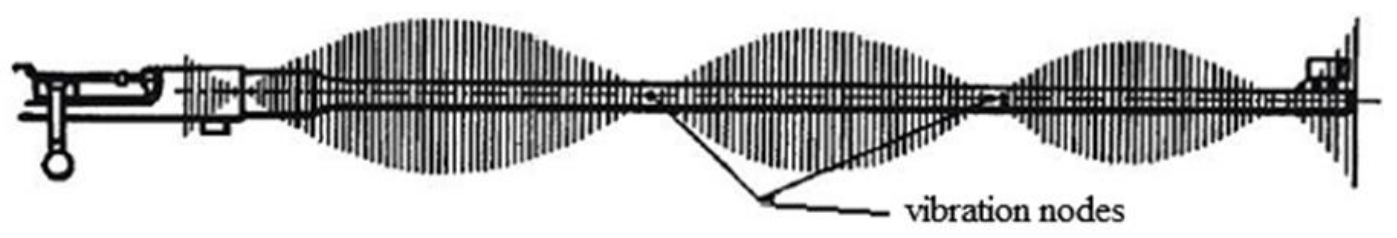

Fig. 5 Oscillations barrel with visible vibration nodes [7]

The amplitude of the points that are distributed at different locations along the barrel is different. It turns out that there are points in the barrel that are relatively calm, called vibration nodes. Simultaneously with the whole barrel, also vibrates the muzzle barrel. It is because the vibrations of barrel start before the bullet leaves the barrel [7].

As the bullet moves through the barrel, the dust gases move away from the cartridge chamber behind the bullet they catch, bouncing off, and colliding with other gases (secondorder gases), coming from the cartridge chamber. We consider these collisions to be normal and not dangerous, if the bore in barrel is free and if we use prescribed ammunition. However, in the shooting practice, there were cases when obstacles appeared in the barrel, e.g. the rest of the cloth after cleaning, pebble, stuck bullet, or clogged muzzle barrel. Exactly the same case can occur when reverse modifying the category D expansion weapons. In such cases, the pressure ratios in the barrel increase dangerously at the point of reflection second-order gases. 
The values of these pressures can reach a level that exceeds the limits of the prescribed elasticity barrel and can seriously damage for example: bulging, or even bursting barrel; see Figure 6 [7].

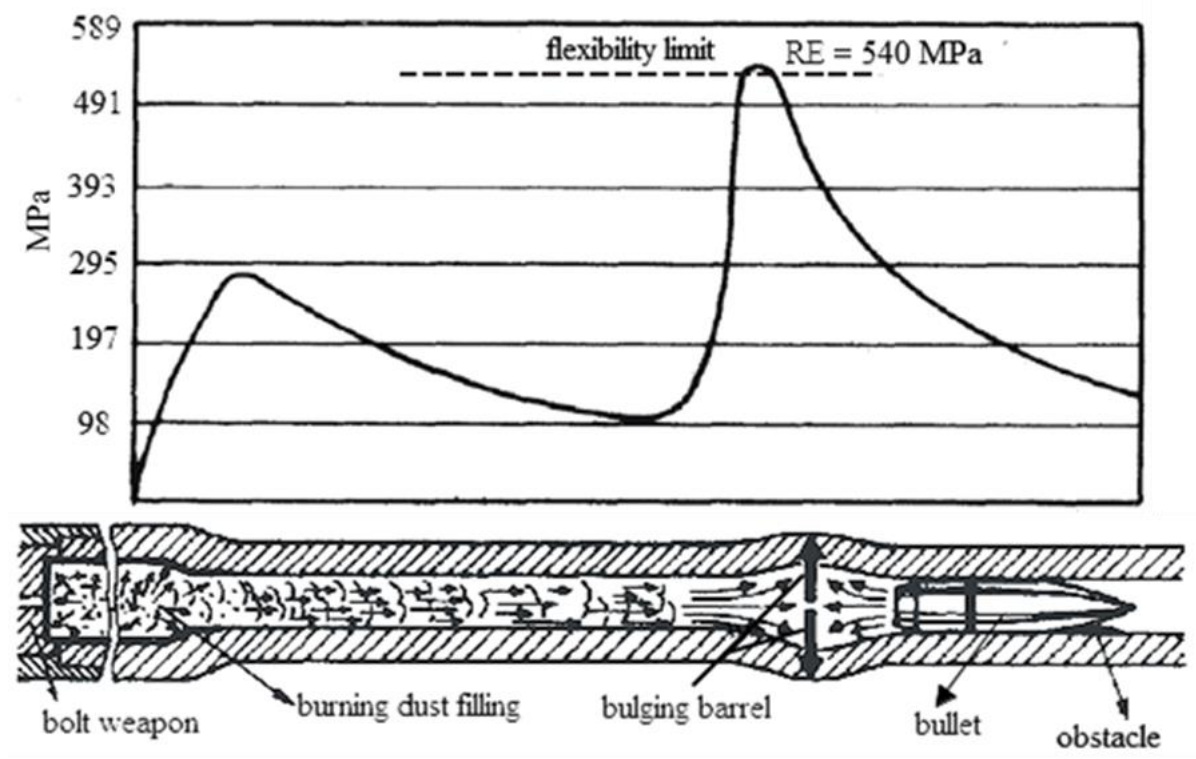

Fig. 6 A schematic representation of the bulge barrel, which is produced by the pressure of the dust gases above the elastic limit [7]

The danger of a breaking barrel is the greater, the greater the speed at which the bullet encounters the obstacle and the nature of the obstacle [7].

Furthermore, it must not be forgotten that some cartridge chambers are also modified for expansion weapons, for example: by using an inserted chambers and then welding it to the barrel; or the cartridge chamber is adapted directly in the barrel by additional drilling for a given type of ammunition. In this case, the reverse modification is already very risky and does not guarantee the reliability of the weapon.

Another important factor that can damage the barrel that has been reversed modification is the reaction to projectile rotation. This is the torque from the motion of the projectile in the grooved barrel, which causes the barrel to rotate in the opposite direction.

Another risk in the actual use of category $\mathrm{D}$ expansion weapons is the high gas pressure at the mouth. We are not talking about reverse modification then. It is used to shoot only blind cartridge, not a sharp cartridge. Despite the lower weight of dust charge (gunpowder), the charge may cause injury to the persons standing in the immediate vicinity of the barrel muzzle, as well as high surface temperatures, especially after firing. If a blind cartridge with a larger grams of dust charge (gunpowder) is used, the cartridge may not burst because it does not have a projectile. The cartridge is simply moulded without a projectile and does not produce such high pressure after ignition of the dust. This risk does not cause damage to the weapon Bolt, nor does it cause damage to the weapon barrel.

\section{CONCLUSION}

Expansion weapons of category D are mainly the focus of reenactors, fans of military history and collectors. These weapons are attractive to this narrow group of people because they do not require possession of a firearm license. Such weapons are used mainly for cultural events related to the reenaction of historical military events. Expansion weapons of category D are used to bring reality and real sound effects closer. These weapons are modified according to 
the law for this purpose. These weapons are also used in cultural events such as various exhibitions, where demonstrations of real shooting are also shown. The technical aspect of the reverse modification and the risks arising from it are very important. The above-mentioned facts, such as the pressure change in the barrel weapon at the shot, where an obstacle from unprofessional and poor quality reverse modification, may also have fatal consequences for the user. It can be stated that the damage barrel does not have to occur immediately after the reverse modification. It is difficult to determine the time period; it depends on the reverse modification and the type of expansion weapon.

The aim of collectors and fans of military history is not reverse modification of the expansion weapons, but only to bring real history closer. However, owing to the events related to the terrorist attacks in France, where the expansion weapons used were reverse modified to sharp weapons, the expansion of the expansion arms in the Slovak Republic was halted to increase security. Cultural events related to military history have also been significantly reduced. The consequence was also a change in legislation (amended Act No. 190/2003) where this situation is sufficiently covered by Section 14a. There is a prohibition on selling such arms over the Internet. For possession of expansion weapons, it would be possible to propose further changes in the abovementioned law, namely: in Section 14, where the age limit of a person for the acquisition and possession of a category $\mathrm{D}$ weapon and thus for an expansion weapon and ammunition increased to 21 years [2].

This change would contribute to reducing the marketability of these weapons, or increasing the age limit for the sale of arms. It is important to mention that the purchase price of expansion weapons is in the order of magnitude higher than that of original weapons without any modification. This will not stop people who want to commit crimes. Such persons will not be stopped by a change in the law. The fact is that crime always finds its way. It can be stated that even radical changes in laws may not always have a positive effect.

The authors of this article do not in any way encourage the sale or increase of the sale of any weapons, including the expansion and other weapons falling under category D by law.

\section{Acknowledgement}

This research output was supported by the Slovak Research and Development Agency under the contract No. APVV-16-0223.

This research output was also supported by the KEGA under the contract No. 030UMB4/2017.

\section{References}

[1] JURÍK, M. 2008. History and present use of short firearms in OZ in SR. Žilina: University of Žilina, Faculty of Special Engineering, Department of Security Management, 57 s.

[2] Zákon 190/2003 Z. z. o strelných zbraniach a strelive a o zmene a doplnení niektorých zákonov (Law 190/2003 on Firearms and Ammunition and on amendments to certain laws).

[3] Vyhláška Úradu pre normalizáciu, metrológiu a skúšobníctvo Slovenskej republiky 169/2015 Z. z.. o technickom postupe pri úprave zbrane kategórie $\mathrm{A}$, kategórie $\mathrm{B}$ alebo kategórie $\mathrm{C}$ na expanznú zbraň kategórie D (Law Office of Standards, Metrology and Testing of the Slovak Republic 169/2015 on the technical procedure for adjusting Category A, Category B and Category C for expansion weapon category D).

[4] Zákon 120/2015 Z. z. ktorým sa mení a dopĺn̆a zákon č. 190/2003 Z. z. o strelných zbraniach a strelive a o zmene a doplnení niektorých zákonov v znení neskorších predpisov a ktorým sa mení zákon Národnej rady Slovenskej republiky č. 145/1995 Z. z. o správnych poplatkoch v znení neskorších predpisov (Law 120/2015 amending and supplementing Law no. 190/2003 on firearms 
and ammunition and amending and supplementing certain acts, as amended, and amending Law of the National Council of the Slovak Republic No. 145/1995 on Administrative Fees as amended).

[5] LIDMILA, Z., LUKEŠ, J., SVOBODA, E. 1999. Strojirenská technologie II: Technologie ve výrobě zbraní a munice (Weapons manufacturing technology). Brno: Military Academy in Brno, 1999. $995 \mathrm{~s}$.

[6] Česká zbrojovka a.s. - Polotovary hlavní (Semi-finished products of barrel) [Online]. [Accessed: 2019-10-9]. Available at http://www.czub.cz/cz/catalog/293-ostatni/OP-OP/CZpolotovaryhlavni.aspx

[7] SCHWARZ, V. 2000. Teória strel'by (Shooting theory). Bratislava: Slovak Shooting Association, $46 \mathrm{~s}$. Internal document.

\section{ORCID}

Pavol Čekan

0000-0002-7435-726X

Daynier Rolando Delgado Sobrino 0000-0001-9253-6141 